Eirik S. Jenssen

Høgskolelektor ved Avdeling for laererutdanning og idrett, Høgskulen i Sogn og Fjordane

Sølvi Lillejord

Professor ved psykologisk fakultet, Universitetet i Bergen

\title{
Tilpasset opplæring: politisk dragkamp om pedagogisk praksis
}

\section{Sammendrag}

Tilpasset opplaering er et populcert politisk virkemiddel når skolen skal reformeres og gjøres $i$ stand til a møte endrede betingelser. Det er et begrep som hentes frem når politikerne skal nå mål som inkludering, sosial utjevning eller økt loeringsutbytte. Evalueringer viser at skoler opplever tilpasset opplaering som et uklart og problematisk begrep. Vi viser $i$ denne artikkelen at loererne har god grunn til a synes at tilpasset opplaering er vanskelig å praktisere. Dette gjør vi ved à vise hvordan tilpasset opploering har skiftet meningsinnhold med skiftende regjeringer i perioden 1975 og frem til i dag. Vi har identifisert fire ulike epoker i tilpasset opplcering som hver fremhever ulike sider ved opploringen og forfekter ulike løsninger.

\section{Innledning}

Tilpasset opplæring har vært et lovfestet prinsipp i norsk grunnskole siden 1975 og i videregående opplæring siden 1998. At opplæringen skal være tilpasset betyr at alle elever har rett til en opplæring som er tilpasset deres evner og forutsetninger. De siste 20 årene har elevpopulasjonen blitt mer sammensatt. I løpet av 1990-årene ble antall minoritetsspråklige elever doblet (Bakken, 2003:11), de sosiale forskjellene i befolkningen øker (St.meld. nr. 16 (20062007):12) og det er stor spredning i elevprestasjoner (Kjærnsli, 2007; Lie, 2001). I de siste års politiske dokumenter har tilpasset opplæring vært omtalt som pedagogisk virkemiddel for å møte disse utfordringene. Forskere peker imidlertid på at tilpasset opplæring oppleves som et vanskelig og uklart begrep av de som skal praktisere det (Bachmann \& Haug, 2006; Engelsen, 2008; Haug, 2006; Imsen, 2003; Lillejord, 2003; Nilsen, 1993; OMI-sluttrapport, 1983; Skaalvik, Fossen \& Skaalvik, 1995).

Denne artikkelen legger til grunn at tilpasset opplæring er et politisk, og ikke et pedagogisk begrep. Fordi det er et politisk begrep vil også hva politikerne mener tilpasset opplæring skal være, skifte innhold med skiftende politiske regimer. Vår gjennomgang av stortingsmeldinger fra 1975 til 2009 viser at hyppige politiske kursendringer trolig gjør det vanskelig for skolene å vite hva 
som er forventet av dem og hvordan de skal praktisere tilpasset opplæring. Vår gjennomgang viser også at politisk brukes begrepet tilpasset opplæring om ulike sider ved opplæringen. Det brukes til å beskrive forhold som gjelder både strukturer, prosesser og resultat i skolen. Vår hensikt er ikke å drøfte ulike funksjoner av tilpasset opplæring, men å undersøke hvordan tilpasset opplæring som begrep gis politisk innhold og hvordan dette politiske innholdet kan gi retning for handling og tiltak på skolenivå. Vi finner at når det gjelder tilpasset opplæring er de politiske budskapene til dels uklare og motstridende fordi meningsinnholdet skifter med skiftende regjeringer i perioden fra $1975 \mathrm{og}$ frem til i dag. Vi konkluderer med at lærere kanskje har god grunn til å synes at det er vanskelig å praktisere tilpasset opplæring.

Fire epoker i tilpasset opplæring

Ved å følge den historiske og utdanningspolitiske aksen til begrepet er det mulig å identifisere ulike epoker i tilpasset opplæring. Fordi de baserer seg på ulike politiske ideologier og verdiorienteringer, fremhever disse epokene ulike sider ved opplæringen og forfekter ulike løsninger. Ved å ta utgangspunkt i sentrale kjennetegn ved hver periode har vi identifisert en integreringsepoke, en inkluderingsepoke, en individualiseringsepoke og en fellesskaps- og kvalitetsepoke. ${ }^{l}$ Det er ikke alltid skarpe skiller mellom de ulike epokene, og særlig i den tidlige fasen er de partipolitiske skillelinjene uklare. Epokene skal derfor oppfattes som analysekategorier.

\section{Første epoke (1975-1990): Tilpasset opplæring som integrering}

En viktig skillelinje når det gjelder tilpasset opplæring kom med lovendringene i 1975. Utdanningssystemet som tidligere var preget av at elevene var plassert $i$ normalskole og spesialskole, ble endret da spesialskoleloven opphørte som egen lov og ble integrert i grunnskoleloven. Flest mulig elever skulle bo hjemme. Det ble en politisk målsetting for hele samfunnet å legge segregasjonen bak seg, og arbeidet med integreringen pågikk over flere år: "Tanken om å integrere mennesker med funksjonsnedsettelser $i$ "normalsamfunnet" ble fremmet i 1950årene, fikk faglig og politisk tilslutning $i$ 1960-årene og nådde full utfoldelse $i$ 1970-årene." (NOU 2001:22:39). Integreringspolitikken hadde en klar sosial legitimering. En sentral side ved skolens oppgave var å "hjelpe elevene til å godta hverandre til tross for innbyrdes forskjeller. På samme måte var det også en oppgave for skolen å hjelpe elevene til å innordne seg et fellesskap og til å bli et verdifullt medlem av en gruppe" (Telhaug \& Mediås, 2003:235). I denne perioden bæres altså prinsippet om tilpasset opplæring oppe av en politisk tro på at skolen kunne bidra til samfunnsendringer. Tanken var at en legger grunnlaget for et mer likeverdig samfunn ved å ha heterogene grupper i skolen og pålegge skolen ansvaret for å lære elevene opp til å godta hverandre. 
Historisk sett var det først og fremst elever med særskilte behov og elever med minoritetskulturell bakgrunn som skulle integreres, men integreringsbølgen fikk store konsekvenser for skolens praksis. Integreringsprosessen medførte at skoletilbudet måtte omstille seg fra segregering til pedagogisk differensiering. Lovfestet rett til opplæring tilpasset evner og forutsetninger, ble en nødvendig forutsetning for den nye enhetsskolen. Prinsippet ble i 1975 uttrykt slik i Lov om grunnskolen § 7-1: "Alle elevar har rett til å få opploering $i$ samsvar med dei evnene og foresetnadene dei har".

I de første årene etter at prinsippet om tilpasset opplæring ble lovfestet, er begrepet sjelden å finne i utdanningspolitiske dokument. I stedet brukes andre begreper som for eksempel organisatorisk og sosial integrering (St.meld. nr 23 (1977-1978) eller alternativ- og utvida opplæring (St.meld. nr. 45 (1980-1981). Vi møter begrepet "tilpasset opplæring" første gang i St.meld. nr. 98 (1976-77) Om spesialundervisning. (Oddvar Nordlis regjering med Kjølv Egeland som kirke- og undervisningsminister). I denne meldingen etableres det en kobling mellom tilpasset opplæring og økonomiske ressurser:

Lovens særregler danner først og fremst grunnlaget for økonomiske ordninger som skal sette kommunen i stand til å gjennomføre en tilpasset individualisert undervisning.

(St.meld. nr. 98 (1976-1977):26)

$\operatorname{og}$

Den enkelte klasses mulighet til å gi tilpasset, differensiert opplæring og et gunstig sosialt miljø for elever med relativt stor spredning i forutsetninger og behov, må styrkes blant annet ved at ressursene til spesialpedagogiske tiltak disponeres innenfor klassens ramme.

(St.meld. nr. 98 (1976-1977):29)

Vi finner også at tilpasset opplæring, i denne integreringsfasen blir forstått som en del av det spesialpedagogiske arbeidet:

Departementet ser det som en sentral spesialpedagogisk oppgave at den enkelte klasses evne og muligheter til å gi tilpasset opplæring og en gunstig ramme for sosial utvikling til elever med stor spredning $\mathrm{i}$ forutsetninger og behov blir videre utviklet $\mathrm{i}$ samsvar med Mønsterplanens retningslinjer.

(St.meld. nr. 98 (1976-1977):29)

Selv om perioden 1981-1990 innebar flere regjeringsskifter, ${ }^{2}$ ser en relativt små ulikheter i fremstillingen av begrepet tilpasset opplæring. Begrepet klargjøres i liten grad og fremstår som svært ullent. På den ene siden blir det gjentatt i flere dokumenter at tilpasset opplæring må forstås som overordnet spesialundervisning. Samtidig blir begreper som "tilpasset opplæring", "spesialundervisning", "differensiering", "utvidet opplæring" og "tilrettelagt opplæring" brukt 
om hverandre og fremstår til dels som synonymer. Av og til bare skilt med skråstrek: "2.2. Spesialundervisning/utvida opplaering/tilpassa opplcering" (St.meld. nr. 62 (1982-1983):19), og "(...) har no kommunane plikt til å syte for tilpassa opplceringstilbod/spesialpedagogisk hjelp til alle barn og unge (...)" (St.meld. nr. 62 (1982-1983):20), og "2.5 Tilpassa opplcering/tilrettelagd opplcering - spesialundervisning" (St.meld. nr. 61 (1984-1985):19). I senere dokumenter finner vi "likeverdig og tilpasset opplaering" (St.meld. nr. 15 (1986-1987):22; St.meld. nr. 43 (1988-1989).

Et første forsøk på begrepsavklaring finner vi i St.meld. nr. 61 (1984-1985) Om visse sider ved spesialundervisninga og den pedagogisk-psykologiske tenesta (Kåre Willochs regjering med kirke- og undervisningsminister Kjell Magne Bondevik):

Tilpassa opplæring eller tilrettelagd opplæring er det overordna omgrepet som uttrykkjer eit sentralt og heilskapleg prinsipp. Spesialundervisning skal fellast inn i denne heilskapen med bakgrunn i dei særlege behova til elevane. Det er ikkje mogleg å definere noko klart skilje mellom det som kan kallast vanleg tilpassa undervisning, og spesialundervisning.(...) Spesialundervisning bør reknast som eit underordna omgrep som stiller krav til meir spesiell ekspertise.

(St.meld. nr. 61 (1984-1985):20)

Her virker kanskje forsøket på å definere begrepene "tilpasset opplæring" og "spesialundervisning" like forvirrende som det er klargjørende. På den ene siden er det snakk om over- og underordnete begreper, men samtidig blir det sagt at det ikke er noe klart skille mellom dem. Når det i tillegg understrekes at spesialundervisning krever spesiell ekspertise, kan en lett få inntrykk av at både spesialundervisning og tilpasset opplæring er noe på siden av det lærere egentlig driver med og er kvalifiserte for.

I samme melding heter det: "Funksjonshemma og vanskelegstilte barn og unge har spesielt krav på ei tilpassa undervisning" (St.meld. nr. 61 (19841985):44). Skal dette forstås som at det er ulike grader av krav, eller er det en omskriving av behov for spesialundervisning? Et lignende utsagn finner vi i et annet dokument noen år senere: "Det er viktig å sikre at de fremmedspråklige elevene får tilpasset opplcering" (St.meld. nr. 43 (1988-1989):83). Slike utsagn bidrar til en oppfatning av tilpasset opplæring som noe ekstra, noe utenom ordinær undervisning, noe som kommer i tillegg.

Mot slutten av 1980-tallet finner vi en av de tidligste politiske konkretiseringene av tilpasset opplæring: "I en skole for alle vil denne tilpasningen måtte gjelde valg og sammensetning av loerestoff, organisering av undervisningen, arbeidsmåter, vurderingsformer, utstyr og laeremidler" (St.meld. nr. 43 (1988-1989):23) (Brundtlands andre regjering med kirke- og undervisningsminister Mary Kvidal). Sitatet angir områder som må tas med i betraktningen når opplæringen skal tilpasses elevene, men uten at meldingen sier noe om innholdet i disse områdene. 
Omfanget av fremmedspråklige elever økte betydelig i perioden 1975-1990, og språklige minoriteter er en gruppe som spesielt nevnes når det er snakk om tilpasset opplæring: "Tilpasset opplcering for dem vil i første rekke si at de må få scerskilt tilrettelagt norskundervisning" (St.meld. nr. 43 (1988-1989):24). Hva "særskilt tilrettelagt" betyr i denne sammenheng er ikke klart. Men at målet er at de fremmedspråklige elevene skal integreres i den "normale" klassen, er det liten tvil om. Etter hvert understrekes behovet for å se integreringen som mer enn en fysisk organisering:

For at en funksjonshemmet skal oppleve tilhørighet til gruppen er det viktig å være med på det som foregår i klassen. Læring bør foregå i et sosialt samspill i en gruppe, på visse felles premisser. Det er ikke nødvendig at alle deltakerne gjør det samme, men det er viktig at aktiviteten blir opplevd som en del av en felles handling og gir hver enkelt mulighet til å realisere sine muligheter.

(St.meld. nr. 54 (1989-1990):21)

I denne første epoken brukes tilpasset opplæring på ulike måter og koples på ulikt sett til økonomi, ressurser, spesialpedagogikk og integrering. Det som kjennetegner perioden er at tilpasset opplæring gjelder spesielle grupper som skal innpasses i fellesskapet. Det ble etter hvert klart at integreringen ikke fungerte $i$ henhold til intensjonene. Alle elever opplevde ikke like stor tilhørighet til læringsfellesskapet. Etter hvert ble det satt i gang ulike tiltak for å hindre uheldig og utilsiktet segregering. Det innebar blant annet andre måter å strukturere opplæring for alle på. Ny politikk trengte andre uttrykksformer, og gradvis ble begrepet integrering erstattet med inkludering.

\section{Andre epoke (1990-1996): Tilpasset opplæring som inkludering}

I denne perioden kommer flere meldinger som danner grunnlaget for Læreplanverket for den 10-årige grunnskolen (L-97). Et sentralt dokument er St.meld. nr. 40 (1992-1993) ...vi smaa en Alen lange (Brundtlands 3. regjering med Gudmund Hernes som kirke-, utdannings- og forskningsminister), som inneholder generell del av læreplanen, og som fortsatt gjelder som forskrift. Her slås det fast at opplæringen må "tilpasses ikke bare fag og stoff, men også alderstrinn og utviklingsnivå, den enkelte elev og den sammensatte klasse" (St.meld. nr. 40 (1992-1993):84). Fellesskap og inkludering er to begrep som går igjen i de utdanningspolitiske dokumentene i denne epoken.

I denne perioden kom også St.meld. nr. 29 (1994-1995) Om prinsipper og retningslinjer for 10-årig grunnskole - ny laereplan, som var et forarbeid til L97. Her blir det tydelig understreket at tilpasset opplæring skal gjelde for alle og på alle områder (evner, forutsetninger, bakgrunn, bosted, likestilling mellom kjønnene, språklige og kulturelle minoriteter). Det slås fast at "Grunnskolen som fellesskap skal vare inkluderende", noe som innebærer at "elever med scerskilte opplaringsbehov skal delta i det sosiale, faglige og kulturelle fellesskapet på en likeverdig måte" (St.meld. nr. 29 (1994-1995):23). Det individuelle perspektivet 
i tilpasningen er tonet ned, og fellesskapet og klassen blir vektlagt også i beskrivelsen av elever med særskilte behov:

Behovet for individuelle utfordringer skal balanseres mot nødvendigheten av felles opplevelser og erfaringer i en inkluderende skole. Valg av lærestoff, bortvalg og tilvalg, skal derfor ta utgangspunkt både i klassens lærestoff og arbeidsmåter og $\mathrm{i}$ elevenes evner og forutsetninger.

(St.meld. nr. 29 (1994-95):23)

Inkluderingsfokuset i denne epokens politiske dokumenter er ikke et særnorsk fenomen, men mer et uttrykk for en global inkluderingsbølge. Norge hadde i 1994 forpliktet seg, sammen med flere andre nasjoner, på en inkluderingsideologi da de undertegnet Salamanca-erklæringen (The Salamanca statement and framework for action on special needs education, 1994). Etter Salamancaerklæringen blir tilpasset opplæring frikoblet fra spesialundervisning, og søkelyset blir rettet mot institusjonenes evne til å inkludere alle $\mathrm{i}$ et likeverdig fellesskap.

Fellesskap står sterkt $i$ et annet viktig utdanningspolitisk dokument i denne perioden, nemlig forarbeidet til ny lovgivning om opplæring fra Smith-utvalget (NOU 1995:18). Her presiseres det at lovtekstens rett til opplæring i samsvar med evner og forutsetninger ikke må forstås slik at alle elever skal ha rett til et individuelt tilrettelagt tilbud (NOU 1995:18). Intensjonene i lovteksten må forstås som et generelt prinsipp som bør realiseres "innenfor rammen av klasseundervisningen" og "i den utstrekning det er mulig" (NOU 1995:18:103).

Smith-utvalget ville videreføre retten til spesialundervisning for elever som har behov for et spesielt tilrettelagt opplæringstilbud. Dette behovet er i henhold til lovteksten knyttet til i hvilken grad eleven făr tilfredsstillende utbytte av den ordinære undervisningen. Smith-utvalget understreker sammenhengen mellom kvaliteten på den ordinære undervisningen og retten til spesialundervisning. Av den grunn "(...), vil en elev som har rett til spesialundervisning $i$ én skole, ikke nødvendigvis ha rett til dette $i$ en annen skole dersom denne skolen i større grad makter å tilpasse det ordinoere opplacringstilbudet og på den måten imøtekomme de ulike elevenes behov" (NOU 1995:18:103). Verdier som trygghet, samhandling, omsorg, fellesskap, tilhørighet, gjensidighet trekkes frem som viktige identitetsmarkører og læringsbetingelser. Smith-utvalgets utredning kopler begrepet tilpasset opplæring til ordinær undervisning og skildrer klassen som en god enhet når det gjelder organisering av undervisning.

Fremstillingen av tilpasset opplæring i denne epoken er svært ulik den som vi fant i den første epoken. Mens forrige periode ga inntrykk av at tilpasset opplæring gjaldt spesielle grupper, blir det i denne epoken tydeligere at tilpasset opplæring skal gjelde for alle og på alle områder. Rammene er fellesskapet og felles stoff. Dette kommer til uttrykk i L-97 som gir klare føringer for innhold og arbeidsmåter. De politiske dokumentene gir imidlertid ingen tydelig innholdsbeskrivelse av tilpasset opplæring, og det blir derfor utfordrende å finne ut 
hva som skiller det fra vanlig undervisning og fra spesialundervisning. Når feltet både er lite konkret og svært omfattende, kan det lett bli uhåndterlig.

Utover 1990-tallet setter oppfatningen av enkeltindividet som utgangspunkt for samfunnets opplysnings- og dannelsesbestrebelser og verdiskapning sitt preg på utdanningspolitikken (Telhaug \& Mediås, 2003), og en ny forståelse av tilpasset opplæring blir introdusert. Gradvis trer individet tydeligere fram mens fellesskapet tones ned. Den tredje epoken faller sammen med regjeringsskiftet i 1997 da sentrumsregjeringen Bondevik I overtok makten, og varer til slutten av Bondevik II-regjeringens tid.

\section{Tredje epoke (1997-2005): Tilpasset opplæring som individualisering}

Denne perioden har tre forskjellige regjeringer: Bondevik I (Jon Lilletun som kirke-, utdannings- og forskningsminister (1997-2000)), Stoltenberg I (Trond Giske som kirke-, utdannings- og forskningsminister (2000-2001)) og Bondevik II (Kristin Clemet som utdannings- og forskningsminister (2001-2005)).

Bondevik I var en samarbeidsregjering mellom Kristelig Folkeparti, Senterpartiet og Venstre, mens Bondevik II var et samarbeid mellom Kristelig Folkeparti, Høyre og Venstre. I de to Bondevikregjeringene kom utdanningsministrene fra ulike politiske partier. Lilletun i Bondevik I representerte $\mathrm{KrF}$ og Clemet i Bondevik II representerte Høyre. De hadde ulik stil som ministre og vektla ulike sider i sentrale utdanningspolitiske spørsmål, som for eksempel synet på enhetsskolen og formålet med et nasjonalt vurderingssystem. Selv om profilen er noe ulik, er imidlertid individualisering dekkende for begge tilnærmingene til tilpasset opplæring.

Lilletun ville avbyråkratisere utdanningssektoren og var opptatt av å flytte makten fra sentralt til lokalt styringsnivå. Han ønsket økt brukerinnflytelse og var opptatt av å spille på lag med lærere og elever, for skolen måtte reformeres nedenfra, mente han (Lilletun, 1999). En viktig del av tilpasningen måtte følgelig skje lokalt ved at lærere og skoleeiere, som kjenner de lokale mulighetene best, legger forholdene til rette. Verdier som fleksibilitet, lokalt handlingsrom og frihet blir tillagt betydelig vekt i flere sentrale politiske dokument i denne perioden (f.eks. St. meld. nr. 23 (1997-1998) Om opplcering av barn, unge og vaksne med scerskilde behov, St.meld. nr. 16 (2001-2002) Kvalitetsreformen: Om ny lcererutdanning.) Dette omtales mot slutten av epoken som et ønsket systemskifte i styringsstrategien av skolen (St.meld. nr. 30 (2003-2004).

Tidlig i perioden (mars 1998) kommer St.meld. nr. 23 (1997-1998) Om opplaering for barn, unge og vaksne med sarskilde behov. Meldingen argumenterer for at de spesialpedagogiske støttesystemene må organiseres slik at de kan ivareta lokale behov. Den viderefører mange av de sentrale verdiene og tankene fra forrige periode, for eksempel taler den varmt om enhetsskolen og viderefører inkluderingstanken. Samtidig settes "eleven i sentrum". Den enkelte elevs behov for tilpasset opplæring og sosial tilhørighet dominerer meldingen. At inkluderingsideologien føres videre i denne meldingen, gir skolene sterke 
signaler om at praktisering av segregerende ordninger er uønsket også når det gjelder elever med særskilte behov. Differensiert og tilpasset opplæring skal fortrinnsvis skje innenfor klassens rammer.

Året etter, i en melding om morsmålopplæring, tar Bondevik I regjeringen imidlertid - noe forvirrende - til orde for organisatorisk differensiering:

Da elevgruppen er svært sammensatt, er det vanskelig å finne ordninger som er fullt ut dekkende for alle grupper. Skal prinsippet om tilpasset opplæring gjennomføres, er det imidlertid mest hensiktsmessig å gruppere elevene etter språklige ferdigheter og i noen grad etter oppholdstid i landet.

(St.meld. nr. 25 (1998-1999):kap 5.7)

Klassen som ramme for tilpasset opplæring, gjelder altså ikke lenger for alle. Det individuelle perspektivet ved tilpasset opplæring blir gradvis sterkere betont. Det skjer bl.a. ved at begrepet "individuelt tilpasset opplæring" stadig oftere omtales som et allment prinsipp:

Arbeidet med å gi elevar og lærlingar likeverdig opplæring i skole (...) må ta utgangspunkt i evner, føresetnader, bakgrunn og interesser hos den enkelte. Dette er grunntanken i prinsippet om individuelt tilpassa opplæring. Dette prinsippet omfattar alle elevane.

(St.meld. nr. 28 (1998-1999:11)

Stoltenbergs første regjering oppnevnte høsten 2001 et utvalg som skulle vurdere kvaliteten i norsk skole (Kvalitetsutvalget). Etter regjeringsskiftet 19. oktober 2001 ble sammensettingen av utvalget noe justert og mandatet noe endret før det ble endelig oppnevnt den 4. desember 2001 av Bondevik II. Tilpasset opplæring ble gjort til et hovedtema i kvalitetsutvalgets arbeid, og utvalget omtaler tilpasning av opplæringen til den enkelte elevs forutsetninger som "den høyeste av alle ambisjoner" (NOU 2003:16:12). A vektlegge individets motivasjon og behov ble sett på som en forutsetning for å bedre den enkeltes læringsutbytte og å heve kvaliteten i skolen:

Å forsterke målsettingen om tilpasset opplæring innebærer en skjerpet oppmerksomhet på den lærende og den lærendes motivasjon og opplæringsbehov. Systematisk oppfølging av kvalitetsutviklingen på individnivå er et viktig virkemiddel i denne ambisjonen. Utvalget har gjennom sine forslag rettet oppmerksomheten mot kvaliteten i læringsutbyttet for den enkelte.

(NOU 2003:16:12)

Kvalitetsutvalget foreslår å forsterke retten til tilpasset opplæring og å fjerne retten til spesialundervisning. Begrunnelsen er at en rekke forskningsarbeider viser at det er vanskelig å dokumentere effekt av ressurskrevende spesialundervisning. Utvalget lanserer begrepet "forsterket tilpasset opplæring" som skal favne både spesialundervisning og tilpasset opplæring. Videre signaliserer 
utvalget tro på at en kan organisere seg til tilpasset opplæring og foreslår at den vanlige klasseinndelingen erstattes av basisgrupper på 12 elever. For, som de skriver: "Basisgruppen skal sikre den enkelte elev en individuelt tilpasset oppfølging" (NOU 2003:16:83).

I St.meld. nr. 30 (2003-2004) Kultur for laering videreførte Bondevik IIregjeringen den sterke vekten på tilpasset opplæring som Kvalitetsutvalget la opp til:

Vi skal strekke oss etter idealet om å gi alle elever tilpasset og differensiert opplæring ut fra deres egne forutsetninger og behov. Alle elever er likeverdige, men ingen av dem er like. Både «teoritrøtte» og «teoritørste» elever skal møtes med respekt.

(St.meld. nr. 30 (2003-2004):3)

Tilpasset og differensiert opplæring fremmes nå som et ideal å strekke seg mot. $\AA$ fremstille tilpasset opplæring som et ideal vekker assosiasjoner om at det kanskje ikke lar seg realisere i praksis. Understrekingen av at det finnes både "teoritrøtte" og "teoritørste" elever er neppe tilfeldig. Flere ganger i denne meldingen kobles tilpasset opplæring til teori og grunnleggende ferdigheter. At tilpasningen skal gjelde hele skolens virke er ikke vektlagt like sterkt som i tidligere perioder. Oppmerksomheten rettes mot målbart læringsutbytte. Videre i sitatet heter det at opplæringen skal tilpasses OG differensieres. Det kan tolkes som at differensiering er en ønsket måte å tilpasse opplæringen på. Senere i meldingen kobles dette til individualisering: "Dertil skal opplceringen differensieres og tilpasses den enkelte elev" (St.meld. nr. 30 (2003-2004):25). Slik får differensiering et klart individuelt preg. Og en kan få assosiasjoner til at hver elev skal ha sin individuelle plan for opplæringen. Dermed blir skillet mellom tilpasset opplæring og spesialundervisning uklart.

Innholdet $\mathrm{i}$ begrepet tilpasset opplæring endres markant ved neste regjeringsskifte da Stoltenberg dannet sin andre regjering. Regjeringsskiftet skjer mens det nye læreplanverket for Kunnskapsløftet sluttføres. Den nye regjeringen rekker å justere og komme med tilføyelser til "Læringsplakaten" eller "Prinsipper for opplæringen" som det ble hetende. Med disse tilføyelsene blir fellesskapet igjen et viktig politisk orienteringspunkt for pedagogisk praksis.

\section{Fjerde epoke (2005-):}

\section{Tilpasset opplæring som læringsfellesskap og undervisningskvalitet}

Stoltenberg dannet sin andre regjering 17. oktober 2005. I nøyaktig to år var Øystein Djupedal (SV) kunnskapsminister. Kunnskapsdepartementet ble så delt mellom Bård Vegar Solhjell (SV) som kunnskapsminister og Tora Aasland (SV) som minister for forskning og høyere utdanning.

I denne epoken retter regjeringen økt oppmerksomhet mot utdanning som verktøy for sosial utjevning. Målet er at bedre tilrettelagt opplæring skal hjelpe flere til å lykkes. Begreper som dominerte i forrige periode (frihet, fleksibilitet, lokalt handlingsrom, individualisme) dempes kraftig og erstattes av begreper 
som likhet, solidaritet og fellesskap. Igjen er det tilpasset opplæring innenfor fellesskapets rammer som skal være fundamentet for fellesskolen (St.meld. nr. 31 (2007-2008).

I denne perioden får vi - kanskje for første gang - en politisk erkjennelse av at tilpasset opplæring oppleves som vanskelig å praktisere. Det skyldes ifølge St.meld. nr. 31 (2007-2008) Kvalitet i skolen, at det har funnet sted en uheldig tolkning av tilpasset opplæring som har fort til en for sterk individualisering. Dette er en praksis regjeringen ønsker å justere. I de politiske dokumentene $\mathrm{i}$ denne epoken er derfor hensynet til den enkelte elev balansert mot hensynet til fellesskapet: "Tilpasset opploering innebcerer høy bevissthet $i$ valg av virkemidler med sikte på å fremme den enkeltes og fellesskapets laering”" (St.meld. nr. 16 (2006-2007):76). Troen på det sosiale fellesskapets positive innvirkning på læringsresultatet er åpenbar:

Elevenes aktivitet, motivasjon og utholdenhet er ikke bare avhengig av forventninger om mestring, men også av positiv samhandling med medelevene. (...) Kompetanseutviklingen hos den enkelte skjer i et sosialt arbeidsfellesskap. Det er det sosiale fellesskapet som hever kvaliteten på den enkeltes læringsarbeid.

(St.meld. nr. 16 (2006-2007):76-77)

Regjeringen finner det nødvendig å repetere det Smith-utvalget presiserte 13 år tidligere: "Departementet vil understreke at tilpasset opploering ikke innebcerer at hver enkelt elev har krav på en individuell plan for sin opplaering, eller at mer tid bør benyttes på individuelt arbeid" (St.meld. nr. 31 (2007-2008):74). Meldingen advarer også mot utstrakt bruk av arbeidsplaner siden det kan gå ut over fellesskapet. Vi ser her en beskrivelse av tilpasset opplæring som avviker grunnleggende fra det synet som ble hevdet $\mathrm{i}$ forrige epoke.

I denne epoken fremheves tilpasset opplæring tydeligere som en kvalitet ved den ordinære undervisningen. Regjeringen søker å klargjøre begrepet tilpasset opplæring ved først og fremst å beskrive det som situasjons- og kontekstavhengig: Det "dreier seg om lokalt å legge til rette betingelser og gi støtte som bidrar til at alle elever får tilfredsstillende utbytte av opplaeringen (...)" (St.meld. nr. 16 (2006-2007):76). På den andre siden ser vi også nye forsøk på å avklare hva innholdet skal være i den opplæringen som er tilpasset. Det kan være forebygging gjennom tidlig innsats, eller ekstra innsats $i$ en avgrenset periode:

Det mangler også tilpassede tilbud til elever som ikke har behov for sakkyndig vurdering og spesialundervisning med individuell opplæringsplan, men som har behov for ekstra støtte og oppfølging i en kortere eller lengre periode

(St.meld. nr. 31. (2007-2008):61) 
Mens tilpasset opplæring i St.meld. nr. 30 (2003-2004) Kultur for laering, ble fremstilt som et ideal å strekke seg mot, blir det i St.meld. nr. 31 (2007-2008) Kvalitet $i$ skolen knyttet til de rammene og ressursene en rår over:

Tilpasset opplæring skal i all hovedsak skje innenfor rammen av fellesskapet, i klasser eller grupper, og på en måte som er håndterlig for lærerne og skolen, noe som blant annet innebærer en forsvarlig ressurssituasjon. Departementet mener opplæringen må legges opp slik at elevene kan dra nytte av at læring skjer i et sosialt arbeidsfellesskap der medelevene er ressurser i læringsarbeidet.

(St.meld. nr. 31 (2007-2008):74)

Regjeringen har ingen tro på at bestemte metoder kan sikre tilpasset opplæring: "Det finnes ingen oppskrift på tilpasset opplæring" (St.meld. nr. 31 (200708):74). God og variert fellesundervisning er veien å gå for å treffe en mangfoldig elevgruppe. Også St.meld. nr. 11 (2008-2009) Lareren - rollen og utdanningen trekker frem kvaliteter i undervisningen som kjennetegn på tilpasset opplæring, og beskriver evnen til å realisere tilpasset opplæring som en kompetanse hos dyktige lærere:

De følger elevenes læring tett opp, og forteller, spør, kontrollerer, repeterer, sanksjonerer, varierer og tilpasser undervisningen til elever og fag. Fleksibilitet og kreativitet er blant de egenskapene som trekkes særskilt fram som betydningsfulle for å tilpasse og variere undervisningen

(St.meld. nr. 11 (2008-2009):13)

Den sterke vektleggingen av ledelsens ansvar for elevenes og skolens læringsutbytte som St.meld. nr. 30 (2003-2004) Kultur for laering tok til orde for, blir videreført i St.meld. nr. 31 (2007-2008) Kvalitet $i$ skolen. Her blir i tillegg skolelederens ansvar for undervisningskvaliteten sterkere vektlagt. Mens det ti år tidligere ble poengtert at: "Kvar enkelt loerar eller instruktør har eit individuelt ansvar for å planleggje og gjennomføre god og tilpassa opplaring, $i$ tråd med generelle og fagspesifikke mål i loereplanverket” (St.meld. nr. 28 (19981999):46), fremheves nå det kollektive i sterkere grad:

Skoler som har spesielt gode resultater, kjennetegnes av en felles skolekultur der lærerne og ledelsen jobber mot felles mål (...) For å kunne lede skolen i riktig retning må rektor ha innsikt i det faglige og pedagogiske arbeidet. Rektor må kjenne til pedagogiske metoder og hva som kjennetegner effektiv undervisning av ulike elevgrupper (...)

(St.meld. nr. 31 (2007-2008):45)

Vi har vist hvordan den politiske omtalen av tilpasset opplæring i denne perioden klart bryter med retorikken fra forrige periode. Det er en bevegelse bort fra det individuelle perspektivet mot å forstå tilpasset opplæring som en kvalitet ved fellesundervisningen. 


\section{Oppsummering og konklusjon}

Som vi oppsummerer i figuren under, har vi identifisert fire epoker hvor tilpasset opplæring blir fremstilt svært ulikt siden lovfestingen av prinsippet $\mathrm{i}$ 1975. I første epoke ble tilpasset opplæring farget av integreringsideologien som preget hele samfunns- og skoledebatten. Tilpasset opplæring ble omtalt som et viktig virkemiddel når marginaliserte grupper skulle integreres i fellesskapet. Selv om loven fastslo at tilpasset opplæring skulle gjelde for alle, ble det fremstilt som noe ekstra og noe som kommer i tillegg til det som lærere driver med til vanlig. Langt på vei omtales tilpasset opplæring i perioden før 1990 som synonymt med spesialundervisning.

\begin{tabular}{|l|l|l|l|}
\hline Epoke & Oppfatning av tilpasset opplæring & Tidsperiode & Regjering \\
\hline I & Tilpasset opplæring som integrering & $1975-1990$ & $\begin{array}{l}\text { Bratteli } \\
\text { Nordli } \\
\text { Brundtland I } \\
\text { Willoch } \\
\text { Brundtland II } \\
\text { Syse }\end{array}$ \\
\hline II & Tilpasset opplæring som inkludering & $1990-1996$ & $\begin{array}{l}\text { Brundtland III } \\
\text { Jagland }\end{array}$ \\
\hline III & Tilpasset opplæring som individualisering & $1997-2005$ & $\begin{array}{l}\text { Bondevik I } \\
\text { Stoltenberg I } \\
\text { Bondevik II }\end{array}$ \\
\hline IV & $\begin{array}{l}\text { Tilpasset opplæring som læringsfellesskap } \\
\text { og undervisningskvalitet }\end{array}$ & 2005-> & Stoltenberg II \\
\hline
\end{tabular}

Tabell 1.0: Ulike politiske epokers oppfatning av tilpasset opploering

I andre epoke er fellesskap, deltakelse, faglig og sosialt utbytte kjerneinnholdet $\mathrm{i}$ skolepolitikken. Vekst i kunnskapen er nasjonalt og internasjonalt et viktig politisk område. Inspirert av utviklingen i USA (The National Commission of Excellence in Education 1983), kan tilpasset opplæring bli knyttet til å få mest mulig ut av nasjonens talent (NOU 1988:28). Samtidig forpliktet vi oss på internasjonale målsettinger om å utvikle demokratiske samfunn hvor alle er sikret rett til deltakelse og fellesskap. Salamanca-erklæringen er et eksempel på en slik målsetting. FNs menneskerettighetserklæring en annen. I skolen skulle elevene inkluderes i fellesskapet og elevene skulle i minst mulig grad tas ut av klassen for $\stackrel{a}{a}$ fa spesialundervisning. Dette utfordret skolens evne til å organisere læringsaktivitetene og fremstå som inkluderende. De fleste stortingsmeldingene i de to første epokene som omhandler tilpasset opplæring, har hovedsakelig tatt opp spørsmål om spesialundervisning og barn med særskilte behov. Dermed er det $\mathrm{i}$ disse meldingene tette koblinger mellom tilpasset opplæring og spesialundervisning. 
Den tredje epoken kjennetegnes ved en tydelig individualisering av tilpasset opplæring. Oppmerksomheten rettes mot det individuelle, og begreper som frihet, fleksibilitet og lokalt handlingsrom dominerer politikken i denne epoken (St.meld. nr. 30 (2003-2004)). Sentral styring er erstattet av økt valgfrihet, og ansvaret for å realisere de politiske målene ligger i stor grad på den enkelte skole. Tilpasset opplæring reduseres i denne epoken til først og fremst å gjelde grunnleggende ferdigheter. Med politiske argumenter fra internasjonale sammenlikninger flettes visjonene om tilpasset opplæring sammen med diskusjonen om Norges konkurransedyktighet internasjonalt. Gjennom større valgfrihet og individuell tilpasset opplæring skal nasjonen hente mest mulig ut av den enkeltes talent (Dale, 2008; Telhaug \& Mediås, 2003; Telhaug, Mediås \& Aasen, 2006).

I den fjerde epoken tones det individuelle ved tilpasset opplæring kraftig ned til fordel for fellesskapet. De politiske dokumentene (f. eks. St. meld. nr. 31 (2007-2008)) sier klart fra hva tilpasset opplæring ikke er, nemlig individuelle opplæringsplaner for den enkelte elev. Et mål i denne epoken er å oppnå tilpasset opplæring ved å heve kvaliteten i undervisningen. Det skal skje ved at begrepene tilpasset opplæring, spesialundervisning og ordinær undervisning alle inngår i skolens undervisningsbegrep og tydeligere ses i sammenheng med hverandre. Spesialundervisning skal ikke oppfattes som isolert fra det vanlige arbeidet i skolen, slik det ofte ble i tidligere meldinger. Dette kommer bl.a. til uttrykk i beskrivelse av tiltak for elever uten sakkyndig vurdering, men med "behov for ekstra støtte og oppfølging i en kortere eller lengre periode" (St.meld. nr. 31 (2007-2008):61). Fra å være skildret som noe ekstra og utenom det lærere vanligvis gjør, beskrives tilpasset opplæring i den fjerde epoken som god og variert undervisning som er slik at flest mulig får tilfredsstillende utbytte av den.

I de politiske dokumentene vi har gjennomgått har begreper som integrering, inkludering og individualisering kommet og forsvunnet, mens tilpasset opplæring har bestått. Det ser altså ut til å være et politisk vellykket begrep fordi ulike regimer kan fylle det med ulikt innhold. For praksisfeltet er det imidlertid - av samme grunn - vanskelig å forholde seg til. Tilpasset opplæring er et prinsipp politikerne henter frem når skolen skal reformeres og rustes til å møte endrede betingelser. Når et politisk-pedagogisk begrep så radikalt skifter innhold som vår gjennomgang viser, er det forståelig at lærere og skoleledere er usikre på hvordan de skal tilpasse opplæringen. Om skolene er usikre på hva tilpasset opplæring innebærer, vil et utfall kunne være at de lar være å gjøre noe. En slik handlingslammelse er problematisk i en tid da det forventes at skolen skal hjelpe den enkelte elev til optimal ytelse. 


\section{Referanser}

Bachmann, K. E., \& Haug, P. (2006). Forskning om tilpasset opplaering. Volda: Høgskulen i Volda.

Bakken, A. (2003). Morsmålsundervisning og skoleprestasjoner. Tidsskrift for ungdomsforskning, 3(1), 21.

Dale, E. L. (2008). Fellesskolen: skolefaglig loering for alle. Oslo: Cappelen akademisk.

Dalen, M. (2006). "'Så langt det er mulig og faglig forsvalig...": Inkludering av elever med spesielle behov i grunnskolen. Oslo: Gyldendal Akademisk.

Engelsen, B. U. (2008). Kunnskapsløftet: sentrale styringssignaler og lokale strategidokumenter. Oslo: Pedagogisk Forskningsinstitutt.

Haug, P. (2006). Begynnaropplæring og tilpassa opplæring. I Haug, P. (red.), Begynnaropploering og tilpassa undervisning. [Bergen]: Caspar forlag.

Imsen, G. (2003). Skolemiljø, lceringsmiljø og elevutbytte: en empirisk studie av grunnskolens 4., 7. og 10. trinn. Trondheim: Tapir akademisk forlag.

Kjærnsli, M. (2007). Tid for tunge løft: norske elevers kompetanse $i$ naturfag, lesing og matematikk i PISA 2006. Oslo: Universitetsforlaget

Lie, S. (2001). Godt rustet for framtida?: norske 15-åringers kompetanse i lesing og realfag $i$ et internasjonalt perspektiv. [Oslo]: Institutt for lærerutdanning og skoleutvikling, Universitetet i Oslo.

Lillejord, S. (2003). Ledelse i en loerende skole. Oslo: Universitetsforlaget.

Lilletun, J. (1999). Jordsmonnet er best nær grasrota. Aftenposten [Kronikk] 23.09.1999,

Nilsen, S. (1993). Undervisningstilpasning i grunnskolen - fra intensjoner til praksis: en kildeanalytisk og deskriptiv-analytisk studie. Universitetet i Oslo, Institutt for spesialpedagogikk, [Oslo].

NOU 1988:28: Med viten og vilje

NOU 1995:18. Ny lovgivning om opplaering: "-og for øvrig kan man gjøre som man vil".

NOU 2001:22. Fra bruker til borger: en strategi for nedbygging av funksjonshemmende.

NOU 2003:16. I første rekke: forsterket kvalitet $i$ en grunnopploering for alle.

OMI-sluttrapport (1983). Sluttrapport fra OMI-prosjektet. Rapport nr 26. Oslo: Universitetsforlaget.

Skaalvik, E. M., Fossen, I., \& Skaalvik, S. (1995). Tilpassing og differensiering: idealer og realiteter $i$ norsk grunnskole. Trondheim: Tapir.

St.meld. nr .98 (1976-1977). Om spesialundervisning.

St.meld. nr. 23 (1977-1978). Funksjonshemmede i samfunnet.

St.meld. nr. 45 (1980-1981). Utdanning og arbeid.

St.meld. nr. 62 (1982-1983). Om grunnskolen.

St.meld. nr. 61 (1984-1985). Om visse sider ved spesialundervisninga og den pedagogiskpsykologiske tenesta.

St.meld. nr. 15 (1986-1987). Om revisjon av Mønsterplan for grunnskolen.

St.meld. nr. 43 (1988-1989). Mer kunnskap til flere.

St.meld. nr. 54 (1989-1990). Om opplaering av barn, unge og voksne med scerskilte behov.

St.meld. nr. 40 (1992-93). ... vi smaa, en alen lange: om 6-åringer $i$ skolen - konsekvenser for skoleløpet og retningslinjer for dets innhold.

St.meld. nr. 29 (1994-95). Om prinsipper og retningslinjer for 10-årig grunnskole: ny laereplan.

St.meld. nr. 23 (1997-1998). Om opploering for barn, unge og vaksne med sarskilde behov: den spesialpedagogiske tiltakskjeda og det statlege støttesystemet.

St.meld. nr. 16 (2001-2002). Kvalitetsreformen: Om ny loererutdanning: Mangfold - krevende - relevant.

St.meld. nr. 25 (1998-1999). Morsmålsopplaering $i$ grunnskolen. 
St.meld. nr. 28 (1998-1999). Mot rikare mål: om einskapsskolen, det likeverdige opploeringstilbodet og ein nasjonal strategi for vurdering og kvalitetsutvikling $i$ grunnskolen og den vidaregåande opploeringa.

St.meld. nr. 30 (2003-2004). Kultur for loering.

St.meld. nr. 16 (2006-2007). -og ingen sto igjen.

St.meld. nr. 31 (2007-2008). Kvalitet $i$ skolen.

St.meld. nr. 11 (2008-2009). Lareren: rollen og utdanningen.

Telhaug, A. O., \& Mediås, O. A. (2003). Grunnskolen som nasjonsbygger: fra statspietisme til nyliberalisme. Oslo: Abstrakt forlag.

Telhaug, A. O., Mediås, O. A., \& Aasen, P. (2006). The Nordic Model in Education: Education as part of the political system in the last 50 years. Scandinavian Journal of Educational Research, 50(3), 245-283.

The National Commission of Excellence in Education (1983): A Nation at Risk: The Imperative for Educational Reform. http://www.ed.gov/pubs/NatAtRisk/index.html

The Salamanca statement and framework for action on special needs education: adopted by the world conference on special needs education : access and quality (1994). [Paris]: Unesco.

\footnotetext{
${ }^{1}$ De tre første kategoriene har klare likhetstrekk med inndelingen bl.a. Monica Dalen (2006) anvender når hun analyserer inkludering $\mathrm{i}$ et skolehistorisk perspektiv.

${ }^{2}$ Brundtland 1. regjering 1981 (8 mnd), Willoch (1981-1986), Brundtland 2. regjering (19861989), Syse (1989-1990)
} 